\title{
Exit the Frog, Enter the Human: Physiology and Experimental Psychology in Nineteenth-Century Astronomy
}

\section{Citation}

Canales, Jimena. 2001. Exit the frog, enter the human: Physiology and experimental psychology in nineteenth-century astronomy. British Journal for the History of Science 34(2): 173-197.

\section{Published Version}

http://dx.doi.org/10.1017/S0007087401004356

\section{Permanent link}

http://nrs.harvard.edu/urn-3:HUL.InstRepos:3210600

\section{Terms of Use}

This article was downloaded from Harvard University's DASH repository, and is made available under the terms and conditions applicable to Other Posted Material, as set forth at http:// nrs.harvard.edu/urn-3:HUL.InstRepos:dash.current.terms-of-use\#LAA

\section{Share Your Story}

The Harvard community has made this article openly available. Please share how this access benefits you. Submit a story.

Accessibility 


\title{
Exit the frog, enter the human: physiology and experimental psychology in nineteenth-century astronomy
}

\author{
JIMENA CANALES*
}

\begin{abstract}
This paper deals with one of the first attempts to measure simple reactions in humans. The Swiss astronomer Adolph Hirsch investigated personal differences in the speed of sensory transmission in order to achieve accuracy in astronomy. His controversial results, however, started an intense debate among both physiologists and astronomers who disagreed on the nature of these differences. Were they due to different eyes or brains, or to differences in skill and education? Furthermore, they debated how to eliminate them. Some, for example, wanted to eliminate the observer, and prescribed the use of new technologies like the electro-chronograph or photography, while others believed in discipline and education. By debating the nature of these differences, astronomers and physiologists sketched both different conceptions of 'man' and different paths to objectivity. These diverse conceptions, moreover, were tied to current nineteenth-century debates, such as the benefits or disadvantages of railroads, telegraphy and the standardization of time and longitudes. By focusing on the debates surrounding the speed of sensory transmission, this paper reevaluates the history of astronomy, physiology and experimental psychology. Furthermore, in investigating astronomy's relation to the human sciences, it uncovers profound connections in the traditionally separate histories of objectivity and the body.
\end{abstract}

L'heure sera distribuée dans les maisons, comme l'eau ou le gaz.

Adolph Hirsch

At first glance, the human sciences and the physical sciences seem to have almost nothing in common. Further investigation, however, reveals the contrary. Not only do they overlap at certain key points, but they also have a common history. ${ }^{1}$ This paper deals with an episode in the history of science where the exact sciences and the sciences of man were

* Department of the History of Science, Harvard University, Cambridge, MA 02138, USA.

I wish to thank Ladina Bezzola, Peter Galison, Kristen Haring, Simon Schaffer, Klaus Staubermann and the participants of the Joint Atlantic Seminar for the History of the Physical Sciences for encouragement and advice. This paper was possible in part thanks to support from the Max Planck Institut für Wissenschaftsgeschichte. I especially want to thank Christoph Hoffmann for transcribing portions of Hirsch's correspondence. All translations from the French and German are mine.

1 During the nineteenth century, according to Michel Foucault, man emerged as a new 'scientific subject' to be studied, surveyed and controlled. Since at first view the exact sciences seem to have little to do with the human sciences, they have been spared Foucauldian analysis. In this paper, however, I explore the connections between the human and the physical sciences, and analyse the relation between the surveillance of the heavens and surveillance of man. 
inextricably intertwined. During the second half of the nineteenth century, the Swiss astronomer Adolph Hirsch (1830-1901) was confronted with problems in astronomy which (he thought) could only be solved by undertaking physiological experiments. ${ }^{2}$ For Hirsch, and for many other astronomers after him, studying man was essential for achieving accuracy in astronomy. By focusing on Hirsch's work, this paper sheds light on the history of astronomy, physiology and early experimental psychology, and by exploring astronomy's relation to the sciences of 'man', I hope to uncover the profound connections between objectivity and the body in nineteenth-century science.

The relationship between the human and the physical sciences has been explored before, particularly in histories of the 'personal equation', as personal differences in astronomical observation were technically called. The 'standard account' of the history of the personal equation, inaugurated by Edwin Boring's History of Experimental Psychology, took the personal equation to be essentially a psychological problem, which 'was destined to become the property of the new physiological psychology ${ }^{3}{ }^{3}$ Although Boring gave a detailed history of the personal equation in astronomy, throughout his work he maintained that 'at bottom the problem is psychological'. ${ }^{4}$

This account, however, has been countered by Simon Schaffer, who criticized Boring's simplistic evocation of the psychologists' solution to the astronomers' problem. ${ }^{5}$ In contrast to Boring, Schaffer recounted how most astronomers competently dealt with the problem of the personal equation from within their own discipline. While some astronomers, like Truman Safford in the late 1890s, placed their hopes on Wundt, according to Schaffer most of them believed 'traditional astronomical methods could cope with personality'. ${ }^{6}$ In this view, astronomy - and not psychology as for Boring - occupied the privileged place in the history of the personal equation. ${ }^{7}$ These two histories have something in common: they place the problem of the personal equation primarily in either

2 For biographical information on Hirsch see R. Gautier, 'Nécrologie', Astronomische Nachrichten (1901), 155, cols. 223-4; E. Legrandroy, 'Adolphe Hirsch', Bulletin de la Société Neuchâteloise des sciences naturelles (1901), 29, 3-21; Lochmann, 'Discours prononcés aux funérailles du Dr. Hirsch: Discours de M. le colonel Lochmann, vice-président de la Commission géodésique suisse', in ibid., 30-2; Morel, 'Discours prononcés aux funérailles du Dr. Hirsch: Discours de M. le professeur Morel, recteur de l'Académie', in ibid., 25-7; David Perret, 'Discours prononcés aux funérailles du Dr. Hirsch: Discours de M. David Perret', in ibid., 32; Quartierla-Tente, 'Discours prononcés aux funérailles du Dr. Hirsch: Discours de M. le conseiller d'Etat Quartier-laTente', in ibid., 22-5. For a history of the Observatory which also contains some biographical details on Hirsch see Département de l'Instruction publique, L'Observatoire cantonal neuchâtelois, 1858-1912: Souvenir de son cinquantenaire et de l'inauguration du Pavillon Hirsch, Neuchâtel, 1912, 1-144.

3 Edwin G. Boring, A History of Experimental Psychology, New York, 1929, 133, and idem, 'The beginning and growth of measurement in psychology', in Quantification: A History of the Meaning of Measurement in the Natural and Social Sciences (ed. Harry Woolf), Indianapolis, 1961, 108-18.

4 Boring, A History of Experimental Psychology, op. cit. (3), 146.

5 Simon Schaffer, 'Astronomers mark time: discipline and the personal equation', Science in Context (1988), $2,115-45$.

6 Schaffer, op. cit. (5), 136.

7 Henning Schmidgen also questions Boring's and Schaffer's accounts. See Henning Schmidgen, 'Zur Genealogie der Reaktionsversuche in der experimentellen Psychologie', in Instrument-Experiment Historischen Studien (ed. Christoph Meinel), Berlin, 2000, 168-79. 
the human sciences (Boring) or in the physical sciences (Schaffer) and minimize the interaction between these two disciplines. By focusing on Adolph Hirsch, who is mentioned only tangentially in Boring, I want to show how the problem of the personal equation was related to both the physical and the human sciences, and not exclusively to one or the other. In this view, questions of objectivity and the body are intimately related.

Historians have traced the origin of psychometry to the work of Franciscus Cornelis Donders. In particular, they located the 'birth of experimental psychology" ${ }^{8}$ in the thesis of Donders's student, Johan Jacob de Jaager. ${ }^{9}$ De Jaager's thesis represented 'the first detailed account of experimental research on the duration of mental operations' ${ }^{10}$ and in Donders's words, it contained 'the first measurement of a well-defined mental process' ${ }^{11}$ Yet, Donders's priority claims notwithstanding, other scientists experimented on the duration of mental processes well before de Jaager. In his work, de Jaager acknowledged three predecessors: the German physiologist Hermann von Helmholtz, the Swiss astronomer Adolph Hirsch and the Dutch ophthalmologist Ludwig Schelske, Donders's associate. $^{12}$

Both Hirsch's and later Schelske's work took place in an astronomical observatory, the former's in Neuchâtel and the latter's in Utrecht. The sole reason (according to de Jaager) why Schelske's experiments were done in an observatory was because an instrument for measuring stellar transits could be adapted for measuring reaction time. ${ }^{13}$ While de Jaager may be correct in claiming Schelske's use of astronomical instruments was merely a matter of convenience, he does not explain why Hirsch, an astronomer trying to measure the difference in longitude between Neuchâtel and Geneva, was involved in the same type of

8 Josef Brozek and Maarten S. Sibinga, foreword to Origins of Psychometry: Johan Jacob de Jaager student of F. C. Donders on Reaction Time and Mental Processes (1865) (ed. and tr. Josef Brozek and Maarten S. Sibinga), Nieuwkoop, Netherlands, 1970, 7-8.

9 Brozek and Sibinga, op. cit. (8), 7-8.

10 Brozek and Sibinga, op. cit. (8), 8.

11 F. C. Donders, 'Over de snelheid van psychische processen', Onderzoekingen gedaan in het Physiologisch Laboratorium der Utrechtse Hoogeschool, Tweede reeks (1868-9), 2, 92-120, 102. Also published as 'Over de snelheid van psychische processen', Nederlandsch Archief voor Genees- en Natuurkunde (1869), 4, 117-45. Published in German in idem, 'Die Schnelligkeit psychischer Prozesse', Archiv für Anatomie, Physiologie und wissenschaftliche Medicin (1868), no. 6, 657-81, and in French in idem, 'La vitesse des actes psychiques', Archives Néerlandaises (1868), 3, 269-317. Translated into English in idem, 'On the speed of mental processes', in Attention and Performance II: Proceedings of the Donders Centenary Symposium on Reaction Time (ed. and tr. W. G. Koster), Amsterdam, 1969, 412-31.

12 Although Hirsch was born in Halberstadt, Germany, he was later naturalized as a Swiss citizen. Adolph Hirsch, 'Rapport du Directeur de l'Observatoire Cantonal à la Commission d'Inspection, pour l'exercise 1865-66', Bulletin de la Société des sciences naturelles de Neuchâtel (1864 à 1867) (1867), 7, Appendix, 1-23, 2 (hereafter BSN).

13 In his thesis de Jaager explained,

Schelske ... conducted in the astronomical observatory some experiments concerning the transmission speed in sensory nerves. The reason for this was that at the observatory there was Krille's apparatus for the registration of stellar transits. This apparatus was made available by Professor Hoek and could easily be modified for the desired purpose.

Brozek and Sibinga, op. cit. (8), 46. Italics mine. 
work. Far from being irrelevant, Hirsch's research in physiology was paramount for astronomers, since it affected the important work of time and longitude determinations, two areas where astronomy was undergoing radical changes. The new electro-chronograph (also known as the American method) was slowly replacing the old eye-and-ear method for measuring stellar transits involved in longitude and time determinations, and Hirsch was one of the first to test the merits of the new instrument. ${ }^{14}$ For astronomers around the world his initial research hinged on these important trials.

This paper begins with an overview of the Neuchâtel Observatory where I explain why its status as a small, governmental observatory was an apt ground for the development of Hirsch's science. Here, I claim Hirsch's defence of the electro-chronograph and of standardization of time and longitudes was part of a republican, unifying effort which eliminated tolls, built railroads, created a new postal system and unified weights, measures and currencies. It is followed by 'Disciplinary transgressions' questioning Boring's 'standard account' and Schaffer's 'Astronomers mark time' and focusing on astronomy's relationship with physiology. While by the end of his life Hirsch was remembered for his contributions to experimental psychology, during his lifetime experimental psychology as a discipline was still in its infancy, and not institutionalized until Wilhelm Wundt inaugurated his famous laboratory in 1879. At the time, Hirsch's work overlapped instead with the well-weathered discipline of physiology. The age-old disciplinary boundaries between astronomy and physiology were strong but, as Hirsch proved, they were not inviolable. In fact, for him and for many others, a profound knowledge of human physiology was essential for obtaining objectivity in astronomy.

In 'Before Hirsch' I map out the possible primary and secondary sources through which he learned of the influential work of Emil du Bois-Reymond, Hermann von Helmholtz and the astronomer Friedrich Bessel. Then 'Hirsch's "temps physiologique"' details Hirsch's experiments, instruments and methods. I explore his motivations for subjecting humans - and not only frogs - to physiological experiments. Here I claim that an essential drive for investigating human physiology arose from the astronomers' search for objective knowledge and I explain the relevance for astronomy of Hirsch's experiments on humans.

In 'Edwin Dunkin and the Greenwich Observatory and Charles Wolf and the Imperial Observatory of Paris' I analyse Hirsch's response to work performed in two highly respected observatories. In my comparison of Hirsch and Wolf I again differ with Schaffer's work, which claims that discipline in the observatory solved the problem of the personal equation. Although indeed some astronomers believed discipline was the panacea, others, like Hirsch, believed it was not the right solution. In fact, astronomers debated different ways to gain objectivity, and these debates were connected to their views on the role of skill, discipline and mechanization in science. Furthermore, by debating the nature of personal differences in observations - and how to eliminate them-astronomers sketched different conceptions of 'man'. While some, like Hirsch, believed personal

14 For the introduction of the electro-chronograph in the United States see Hugh Richard Slotten, 'The dilemmas of science in the United States: Alexander Dallas Bache and the U. S. coast survey', Isis (March 1993), $84,26-49,41-2$. 
differences were due mainly to different brains, others, like Wolf, believed they were mainly due to different levels of skill and education.

In this section I also place Hirsch's experiments in the larger context of nineteenthcentury astronomy. Historians of astronomy have often noted that during the nineteenth century astronomical knowledge came to rely increasingly on other sciences, especially chemistry. This epistemological change has been called the 'new astronomy', and is characterized by the emergence of physical astronomy. While this paper as a whole analyses debates surrounding the alleged physiological nature of visual effects present in astronomical observations, I here relate how some astronomers believed these effects were arrested at the retinal level and others believed they were cerebral. In fact, not only was the accuracy of astronomical observations at stake in these debates, but even the physical reality of certain astronomical effects was contested. While for Wolf the strength of stellar light on the observer's eyes was of prime importance, Hirsch protested that the actual strength of astrophysical effects on the eyes was largely exaggerated by Wolf, and instead took them to be primarily a mere product of the brain. Only further research on human physiology, Hirsch claimed, could settle these essential questions.

In 'Sigmund Exner in Vienna' I relate Hirsch's exchange with the important Viennese physiologist who coined the term 'reaction time' for the personal equation, and conclude with 'Clockwork human', exploring Hirsch's conception of instruments and his treatment of observers as part of these instruments. Hirsch not only fought against the individuality of observers but, analogously, also studied the individuality of instruments and how to eliminate it. Thematically, this last section is a mirror image of the first sections. While I first focus on Hirsch's comparison of observers with precision instruments, I then study how this relationship was reversed and focus on how Hirsch also viewed instruments as similar or different from observers.

\section{Neuchâtel - not Paris}

The Neuchâtel Observatory, where Hirsch worked since its creation in the spring of 1859, was different from other important European observatories, especially Greenwich and Paris. Hirsch, having been Franz Encke's assistant in Berlin and Urbain Le Verrier's in the Imperial Observatory in Paris, was well aware of these differences and used them to his advantage. ${ }^{15}$ The salient characteristics of the Neuchâtel Observatory were its small size and mundane orientation. In its beginning, it only had two instruments and one astronomer and, like the observatory in Geneva, it was founded for the sole purpose of promoting the Swiss timekeeping industry. ${ }^{16}$ 'The Neuchâtel Observatory', Hirsch wrote,

15 Hirsch studied in Heidelberg, Berlin (with Franz Encke), Vienna and Paris (with Urbain Le Verrier).

16 Hirsch later asked for a mécanicien-concierge, an aide-astronome and for the creation of a chair of astronomy in the Académie de Neuchâtel, to which he was nominated at its founding in 1866. The aide-astronome from 1864 to 1871 was Alexander Schmidt. Adolph Hirsch, 'Rapport du Directeur de l'Observatoire Cantonal a la Commission d'Inspection pour 1864-1865', BSN (1864 à 1867) (1867), 7, Appendix, 1-15, 1, 15. 
'was founded with an essentially practical goal: the determination of astronomical time for use by the clockwork industry. And its organization is particularly calculated to fulfil that goal to the highest possible degree' ${ }^{17}$ Hirsch knew his small, third-rate observatory could not compete against large observatories. In a description of the Observatory, he lamented, 'It is clear that because of its very limited resources in terms of instruments and personnel, the Neuchâtel Observatory cannot compete against large observatories of first or even second rate. ${ }^{18}$ Furthermore, there were certain areas of astronomy that his observatory could not dream of reaching, like physical or stellar astronomy. ${ }^{19}$ Since he did not have 'a considerable number of observers, or even a bureau of calculations dedicated to reducing the tiresome, time-consuming observations,${ }^{20}$ he was forced to limit his astronomy to the sphere of known planets and comets, for even the discovery of new ones was beyond his means. ${ }^{21}$

Within these limits, however, the Neuchâtel Observatory could, and was expected to, excel in one area: time. ${ }^{22}$ Time was important in another respect: longitudes could be

17 Adolph Hirsch, 'Notice sur l'établissement de l'observatoire à Neuchâtel', BSN (1859 à 1861) (1861), 5, $60-5,60$.

18 Hirsch, op. cit. (17).

19 As Hirsch noted,

There are entire spheres of astronomy which remain inaccessible to it. These are primarily investigations on physical astronomy, which demand optical resources we do not have. Also, it will be impossible for us to participate in the great enterprises of stellar astronomy, which occupy the best observatories, like Greenwich, Poulkova, Berlin, Vienna, Paris etc., and whose goal is to extend and precisely determine our knowledge of the stars, and to create great catalogues and celestial maps.

Hirsch, op. cit. (17), 60-1.

20 Hirsch, op. cit. (17), 61.

21 The Observatory's small size was later turned to advantage. At one point Hirsch concluded from his experiments that observers should be repeatedly measured for their personal corrections before attempting to measure time and longitudes. Measuring for the personal corrections of each different observer, however, was extremely time-consuming and laborious, and large observatories, with many observers, would carry most of the burden of his prescription. In his work on longitude determination between Geneva and Neuchâtel, Hirsch stressed the perils of observatories 'where many observers do the same work, as is the case in most of the large observatories', since 'it is necessary that they determine their personal corrections not once and for all, but during short intervals of time'. Hirsch successfully turned a weakness into strength by setting a new standard for time determinations that decisively benefited small observatories with few observers. 'This determination of the personal correction is necessary every time one deals with absolute determination of time.' Emile Plantamour and Adolph Hirsch, 'Détermination télegraphique de la différence de longitude entre les observatoires de Genève et de Neuchâtel', Mémoires de la Société de physique et d'histoire naturelle de Genève (1864), 17, 289-435, 394.

22 For the Neuchâtel clock and telegraph industry see Simon Newcomb, 'The watchmaking industry in Switzerland', Science: A Weekly Record of Scientific Progress (1883), 1, 296-7; A. Bachelin, L'Horlogerie neuchâteloise, Neuchâtel, 1888; E. Quartier-la-Tente, Le Canton de Neuchâtel: Revue historique et monographique des communes $d u$ canton d l'origine à nos jours (number of volumes unknown), Neuchâtel, 1898, ii, 525-6; ibid., 1901, iii, 408-9; David S. Landes, Revolution in Time: Clocks and the Making of the Modern World, Cambridge, MA, 1983; William Gray Eberly, 'Neuchâtel: a place, a clock, a symbol', National Association of Watch and Clock Collectors Bulletin (February 1993), 35, 26-32. For the material culture of Swiss time-keeping in a later period see Peter Galison, 'Einstein's clocks: the place of time', Critical Inquiry (Winter 2000), 26, 355-89. 
found by comparing the sidereal time of different places with the aid of the telegraph, and Hirsch devoted himself to these national enterprises. ${ }^{23}$

Built for and by the state, the Observatory participated in the gargantuan task of nationbuilding. Its creation resulted from the political victory of the Swiss Confederation over the separatist league of Roman Catholic cantons known as the Sonderbund. While the separatist cantons supported a diversity of currencies, laws, postal services, weights, measures and even armies, the Confederation fought for standardization in these areas. ${ }^{24}$ It is important to note that the Grand Conseil approved the project for the Observatory only after the confederates' victory in a brief civil war against the Catholic Sonderbund, and only after Neuchâtel was completely incorporated into the Swiss Confederation. ${ }^{25}$ After the Swiss civil wars, the governmental Observatory was established alongside a new, unified currency, constitution and army. The Observatory, with Hirsch's defence of the unification of time, longitudes, weights and measurements (as well as his known antiCatholic virulence), was a powerful ally of the new, confederate republic. As part of these broader socio-political transformations, Hirsch undertook the important studies that would later become the cornerstone of experimental psychology. ${ }^{26}$

The republican and federalist roots of the Neuchâtel governmental Observatory cannot be underestimated. Despite the republican victory in the Sonderbundskrieg of 1848, the creation of the Observatory had to wait until Neuchâtel's full integration into the Swiss Confederacy in 1857. Since 1707 Neuchâtel had been a principality of the King of Prussia and in 1815, after the Napoleonic Wars, it gained an ambiguous, dual status by also becoming a canton of the Swiss Confederation. During the civil war of 1848 Frederick William IV, King of Prussia, took the side of the conservative Sonderbund and, faithful to the wishes of its monarch, Neuchâtel remained neutral. Yet, following the successful revolution in Paris where Louis Philippe and the royalists were overthrown, republican fervor gripped Neuchâtel, and on 1 March 1848 armed rebels unfurled the Swiss cross flag

23 By working on longitude determinations, Hirsch also contributed to the age-old debate of the shape of the earth. For a history of the debate see I. Todhunter, A History of the Mathematical Theories of Attraction and the Figure of the Earth: From the Time of Newton to that of Laplace, 2 vols., London, 1873. For the eighteenth century see Mary Terrall, 'Representing the Earth's shape: the polemics surrounding Maupertuis's expedition to Lapland', Isis (1992), 83, 218-37.

24 For the politics of standardization in a different context see Ken Alder, 'A revolution to measure: the political economy of the metric system in France', in The Values of Precision (ed. M. Norton Wise), Princeton, 1995, 39-71.

25 Legrandroy, op. cit. (2); Aimé Humbert, directeur de l'instruction publique at the time, was a strong proponent of the Observatory and influential in bringing Hipp to Neuchâtel. He wrote a thorough history of the rise of the Neuchâtel Republic that is excellent on railroads. Aimé Humbert, Alexis-Marie Piaget d'après sa correspondance et la République Neuchâteloise de 1848 à 1858, 2 vols., Neuchâtel, 1888-95.

26 Hirsch was one of the most active members of the Swiss Geodesic Commission, where he was secretary for thirty-one years and president after 1893. From 1864 he represented Switzerland in the permanent Geodesic Commission, and was secretary of the Conférences de l'Association pour la mésure des degrés en Europe, which became the International Geodesic Association in 1886 with Hirsch as permanent secretary. In conjunction with his participation in international geodesic research, he was secretary, for twenty-five years, of the Comité internationale des poids et mésures. 
where once flew the Prussian eagle. ${ }^{27}$ Although the new republic was sanctioned by the Swiss Confederacy and by the people of Neuchatel, the King, busy with the threat of revolution in Berlin, did not relinquish his territory. Neuchâtel had to wait until 1857, after a royalist insurrection backfired, to become fully integrated into Switzerland. This final integration permitted Neuchâtel to participate in the network of confederate institutions rapidly crisscrossing Switzerland. As part of this effort the Grand Conseil finally approved the project for the Observatory.

The new Confederation eliminated highway, bridge and other internal tolls, created a new postal system and unified coinage, weights and measures. Along with this standardization effort, the federal government undertook the immense task of networking Switzerland with railways and with the recently invented electric telegraph. ${ }^{28}$ Like the confederates, Hirsch strongly advocated the use of the electric telegraph, and his efforts towards unification of measures of longitude and time (for which the railway companies clamoured), as well as his never-ending defence of 'institutions of all sorts which provide communications from village to village', can only be seen as part of the much-contested republicanism which was gripping Europe in general and Switzerland in particular. ${ }^{29}$

Hirsch knew the national calling of the governmental Neuchâtel Observatory was the precise determination of time and its distribution to important clock-making centres. By distributing time through telegraph wires, the Observatory could raise an important national industry to a competitive level, for only then could clock-makers calibrate and test their instruments against an accepted standard. Prophetically, Hirsch wrote, 'Time will be distributed to homes, like water or gas. ${ }^{30}$ Throughout his years as director, he repeatedly explained how 'the brilliant development of our precision clockwork industry ... is in great part due to the distribution of astronomical time ${ }^{31}$, and one of his central tasks was to rate the best chronometers to prevent Switzerland from 'becoming the slave of other countries ${ }^{32}$ by contributing, in many ways, to the clockwork industry.

27 Heinrich Zschokke and Emil Zschokke, The History of Switzerland for the Swiss People (tr. Francis George Shaw), New York, 1860, 390-1.

28 Wilhelm Oechsli, History of Switzerland 1499-1914 (tr. Eden and Cedar Paul), Cambridge, 1922, 401. Not coincidentally, Hipp, who was in charge of the Neuchâtel telegraph factory, had been previously arrested as a dangerous republican.

29 Adolph Hirsch, 'Rapport de M. A. Hirsch, lu dans la 1re séance de la Conférence, le 15 octobre 1883', in R. Gautier, 'L'unification des longitudes et l'introduction d'une heure universelle', Archives des sciences physiques et naturelles (1884), 11, 594-601, 597-8.

30 Adolph Hirsch, 'Sur la réorganisation de la transmision télégraphique de l'heure de l'Observatoire', BSN (1874 à 1876) (1876), 10, 245-52, 252.

31 Hirsch, op. cit. (30), 246. The same point was stated again in idem, 'Sur la transmission électrique de l'heure à travers un réseau télégraphique', BSN (1861 à 1864) (1864), 6, 373-9, 373, and in idem, 'Rapport du Directeur de l'Observatoire Cantonal à la Commission d'Inspection pour l'exercise 1874', BSN (1874 à 1876) (1876), 10, Appendix, 1-29, 4.

32 In this same report Hirsch suggested Switzerland should follow France in creating schools for clock-making, and should prohibit the sale of faulty clocks. Adolph Hirsch, 'Rapport du Directeur de l'Observatoire Cantonal à la Commission d'Inspection de cet établissement pour l'exercise 1862-63', BSN (1861 à 1864) (1864), 6, Appendix, 1-27, 11, 25-7. 


\section{Disciplinary transgressions}

In his Cours de philosophie positive Auguste Comte inveighed against the threatening disciplinary transgressions in science. Fervently attempting to restore order, he explained how different scientific disciplines should be logically ordered and categorized from the most exact to the least. Astronomy crowned his fragile, positive edifice. Comte expounded on the merits of astronomy, which stood high above the 'lesser' sciences. ${ }^{33}$ Although in Comte's hierarchy physics sat clearly below astronomy, he acknowledged that sometimes 'several branches of physics, especially optics, were indispensable to the complete exposition of astronomy'. ${ }^{34}$ Yet unfortunate instances like these, in which a lesser discipline (in this case physics) was used in a higher one (astronomy), were "minor defects' - the exception and not the rule. ${ }^{35}$ Despite positivism's enormous popularity during the second part of the nineteenth century, Comte's hopeful prediction that 'the positive knowledge we can have of the stars is limited solely to their geometrical and mechanical phenomena, and can never be extended by physical, chemical, physiological and social research' was forcefully proven wrong during the course of the nineteenth century. ${ }^{36}$ Instances where 'lesser' sciences were invoked for understanding the exact sciences abound, in Hirsch and elsewhere.

Shortly after becoming director of the Observatory, Hirsch started to mix physiology and astronomy. In November 1861 the Société des sciences naturelles de Neuchâtel announced the curious work of its Director. At first, these investigations did not seem to pertain to astronomy; except for the fact that they were performed by an astronomer at an observatory. With no explicit references to astronomy, the Société vaguely remarked on Hirsch's 'interesting experiments for measuring the elapsed time between the instant a phenomenon takes place and the time when an experimental subject acknowledges he has sensed that phenomenon'. ${ }^{37}$ These initial experiments, however, were shortly thereafter interrupted by technical difficulties with his chief instrument, the Hipp chronoscope, which could measure short intervals of time (even the speed of bullets ${ }^{38}$ ) and which later became

\section{As Hirsch noted,}

Astronomical phenomena being the most general, simple and abstract of all, the study of natural philosophy must evidently begin with them, for the laws of astronomy influence those of all other phenomena, but the laws of other phenomena do not influence those of astronomy.

Auguste Comte, Introduction to Positive Philosophy (ed. and revised tr. Frederick Ferré), Indianapolis, 1988, 54.

34 Comte, op. cit. (33), 50.

35 Comte, op. cit. (33), 50.

36 Auguste Comte, cited in Michael J. Crowe, Modern Theories of the Universe from Herschel to Hubble, New York, 1994, 147.

37 Louis Coulon, 'Séance du 8 Novembre 1861', BSN (1861 à 1864) (1864), 6, 6-7.

38 For the reference to the measurement of bullet speeds see Plantamour and Hirsch, op. cit. (21), 380. For the military background of timing and graphic devices see Hebbel E. Hoff and L. A. Geddes, 'The technological background of physiological discovery: ballistics and the graphic method', Journal of the History of Medicine and Allied Sciences (1960), 15, 345-63; Christoph Hoffmann, 'Ernst Mach und Peter Salcher: Photographische 
a staple instrument for experimental psychologists worldwide. ${ }^{39}$ Six months passed before Hirsch was able to continue his 'expériences intéressantes'. This time (May 1862) the Société acknowledged that Hirsch's work concerned both astronomy and physiology: 'Hirsch has restarted his experiments on the physiological time which intervenes in astronomical observations. ${ }^{40}$ Studying physiology to understand astronomy was a strange idea. And Hirsch anticipated the reaction of fellow scientists to this unholy mix. At the beginning of his paper, he prepared the audience for a possible shock: 'I must, first of all, be aware of your amazement at seeing experiments of this genre carried out in an astronomical observatory. ${ }^{41}$

\section{Before Hirsch}

According to Hirsch, the works of Emil du Bois-Reymond and Hermann von Helmholtz were his principal influences. He encountered the work of these two scientists in a letter published in the Revue suisse under the title 'On measuring thought', explaining the work of Helmholtz, du Bois-Reymond, and Friedrich Bessel. ${ }^{42}$ The letter, written by the German theologian, politician and scientific writer Otto Ule, was sent to the geologist Eduard Desor, friend of the renowned naturalist Louis Agassiz and a prime force in establishing Hirsch's Observatory and Matthäus Hipp's telegraph and electric-clock factory. ${ }^{43}$ Instead of referring directly to the original research of du Bois-Reymond, Helmholtz and Bessel, Hirsch relied on Ule's summary of these works. ${ }^{44}$ From its description of du Bois-

Fixierung der durch Projectile in der Luft eingeleiteten Vorgänge (1887)', Fotogeschichte: Beiträge zur Geschichte und Ästhetik der Fotografie (1996), 16, 3-18; Christoph Hoffmann and Peter Brez (eds.), Über Schall: Ernst Machs und Peter Salchers Geschoßfotografien, Göttingen, 2001.

39 For the history of Hipp and his chronoscope see Fairfid M. Caudle, 'The developing technology of apparatus in psychology's early laboratories', Annals of the New York Academy of Sciences (1983), 412, 19-56; Anton Lübke, Das grosse Uhrenbuch: Von der Sonnenubr zur Atomuhr, Tübingen, 1977, 392; Aymon de Mestral, 'Mathias Hipp 1813-1893', in Pionniers suisses de l'économie et de la technique (ed. Institut d'études économiques), Zurich, 1960, 9-34; Schmidgen, op. cit. (7); Werner Traxel, Horst Gundlach and Ulrich Zschuppe, 'Zur Geschichte der apparativen Hilfsmittel der Psychologie', in Handbuch apparativer Verfahren in der Psychologie (ed. Rolf Brickenkamp), Göttingen, 1986, 1-22, 3, 6, 20; Adolph Hirsch, 'Quelques détails biographiques sur M. Hipp', BSN (1893), 21, 199-200.

40 Louis Coulon, 'Séance du 30 Mai 1862', BSN (1861 à 1864) (1864), 6, 64-70, 64. Italics mine.

41 Adolph Hirsch, 'Expériences chronoscopiques sur la vitesse des différentes sensations et de la transmission nerveuse', BSN (1861 à 1864) (1864), 6, 100-14, 100.

42 Otto Eduard Vincenz Ule, 'Sur les moyens de mésurer la pensée: Lettre de M. Ule à M. E. Desor', Revue suisse (1857), 20, 197-202.

43 Legrandroy, op. cit. (2), 4, and de Mestral, op. cit. (39), 25.

44 Current research in 'reader response' has warned historians of how readers are not a blank slate upon which texts are deposited, but rather shape and understand texts in a particular and active way. In this paper I take for granted that Hirsch's reading of, for example, Bessel may not correspond exactly with what Bessel himself wanted to convey. Although Hirsch directly cited Emil du Bois-Reymond's Untersuchungen über thierische Electricität he never directly cited Bessel or Helmholtz; rather he cited Ule on Helmholtz and Bessel, and Hervé Faye on Bessel. Helmholtz's relevant works on the speed of nervous transmission are H. Helmholtz, 'Vorläufiger Bericht über die Fortpflanzungsgeschwindigkeit der Nervenreizung (Aus dem Monatsbericht der K. Akademie der Wissenschaften Januar 1850)', Archiv für Anatomie, Physiologie und wissenschaftiche Medicin, von Dr. 
Reymond's work, he became aware that the 'nervous action is probably nothing other than an electrical phenomenon' ${ }^{45}$ and that, like electrical phenomena, it had a finite velocity. The letter described Helmholtz's work on nervous transmission in more detail, and listed his main conclusions. First, the speed of transmission of sensory nerves was around fiftyfour meters per second, and was nearly the same for all individuals. Second, "under the most favorable conditions and with a highly sustained attention, the brain needs at least 0.1 seconds for transmitting its orders to the nerves which conduct voluntary movements'. Third, the speed of transmission of motor nerves was almost the same as that of sensory nerves, taking approximately 0.01 seconds. Fourth, 'the complete task takes some $1 \frac{1}{4}$ to 2 tenths of a second' ${ }^{46}$ Ule did not go into any more detail about Helmholtz's work, but added that these numbers could be obtained by timing a person's reaction to an electric shock. Also, the time taken by the brain could be separated from the speed of nervous transmission by applying the shock to body areas located at different distances from the brain (this method later became known as the 'method of different nerve lengths'): 'That way one finds that an [electric] shock applied to the toe is 0.33 seconds slower than a shock applied to the ear or face.' 'Evidently', Ule concluded, 'this difference does not depend on the brain, but on [nerve] transmission'. ${ }^{47}$

According to Ule, 'astronomers were first' in finding 'the ways of measuring thought', and the 'famous Bessel' was the first to notice a discrepancy when different observers simultaneously estimated, from the beats of a pendulum, the time of a star's passage across the wires of a transit instrument. Furthermore (according to Ule) Bessel noticed that these differences in observation remained fixed among the same observers, but varied with different observers. He continued explaining how Bessel believed these discrepancies were due to 'the individuality of astronomers', and how visual and auditory phenomena could

Johannes Müller (1850), no. 1,71-3; idem, 'Messungen über den zeitlichen Verlauf der Zuckung animalischer Muskeln und die Fortpflanzungsgeschwindigkeit der Reizung in den Nerven', in ibid., no. 3, 276-364; idem, 'Fortpflanzungsgeschwindigkeit der Nervenreizung', Bericht über die zur Bekanntmachung geeigneten Verhandlungen der Königliche Preussische Akademie der Wissenschaften zu Berlin (1850), 14-15; idem, 'Note sur la vitesse de propagation de l'agent nerveux dans les nerfs rachidiens. (Note de M. Helmholtz, de Koeningsberg, transmise par M. Humboldt.)', Comptes rendus hebdomadaires (25 February 1850), 30, 204-6; idem, 'Ueber die Methoden, kleinste Zeittheile zu messen, und ihre Anwendung für physiologische Zwecke', Königsberger Naturwissenschaftliche Unterhaltungen (1851), 2, 169-89; idem, 'Messungen über Fortpflanzungsgeschwindigkeit der Reizung in den Nerven', Archiv für Anatomie, Physiologie und wissenschaftiche Medicin, von Dr. Johannes Müller (1852), no. 2, 199-216. For Faye's description of Bessel's work see Hervé Faye 'Sur les erreurs d'origine physiologique', Comptes rendus hebdomadaires (12 September 1864), 59, 473-80. For excellent accounts of Helmholtz's papers see Frederic L. Holmes and Kathryn M. Olesko, 'The images of precision: Helmholtz and the graphical method in physiology', in The Values of Precision (ed. M. Norton Wise), Princeton, NJ, 1995, 198-221; Kathryn M. Olesko and Frederic L. Holmes, 'Experiment, quantification, and discovery: Helmholtz's early physiological researches, 1843-50', in Hermann von Helmboltz and the Foundations of Nineteenth-Century Science (ed. David Cahan), Berkeley, CA, 1993, 50-108; Robert M. Brain, 'The graphic method: inscription, visualization, and measurement in 19th-century science and culture', (Ph.D. thesis, University of California, Los Angeles, 1996); Robert M. Brain and M. Norton Wise, 'Muscles and engines: indicator diagrams and Helmholtz's graphical methods', in Universalgenie Helmholtz (ed. Lorenz Krüger), Berlin, 124-45; reprinted in Mario Biagioli (ed.), The Science Studies Reader, New York, 1999, 51-66.

45 Hirsch, op. cit. (41), 102.

46 Ule, op. cit. (42), 202.

47 Ule, op. cit. (42), 201. 
not be sensed simultaneously, but only successively. Despite the primacy attributed to the astronomers, for Ule they were not indispensable: 'there is no need to be an astronomer for engaging in this type of experiments', because other similar examples could be found in 'ordinary life'. For example, it was impossible to observe scintillating luminous impressions separated by less than a tenth of a second, or to hear more than thirty-two vibrations in a second.

\section{Hirsch's 'temps physiologique'}

Careful not to trespass too much on the physiologist's turf, Hirsch stressed how his interests differed from theirs since his concerned primarily astronomy: 'Since this type of work belongs to the physiologists, I would not have undertaken it if I had not had the special goal I mentioned: I have especially dedicated myself to determining the speed of physiological operations involved in astronomical observations. ${ }^{48}$ Initially, his investigations were limited to measuring the 'temps physiologique', Hirsch's term for the different times observers needed to react to a sense impression. His temps physiologique consisted of three elements, analogous to those which appeared in Ule's description of Helmholtz's work: first, 'the transmission of sensation to the brain'; second, 'the action of the brain, which consists of transforming sensation into a volitional act'; third, 'the transmission of volition through the motor nerves, and the execution of muscular movement'. ${ }^{49}$ Hirsch concluded at first 'that it is extremely difficult, if not impossible, to separate' these three elements. ${ }^{50}$ And although for his astronomical concerns he did not need to separate them, he still tried, proving it was 'difficult', though not impossible. ${ }^{51}$ But first, he needed to measure the whole temps physiologique and then proceeded to measure on himself and his friends the time needed to react to auditory, visual and tactual stimuli. ${ }^{52}$

Hirsch knew tests on tactual stimuli bore almost no importance to his astronomical researches, but he persisted because they might help separate the makeup of the temps physiologique-and that had a 'special' importance: 'The experiments on the physiological time of touch, although they have less to do with astronomical observations,

48 Hirsch, op. cit. (41), 103.

49 Hirsch, op. cit. (41), 103-4.

50 Hirsch, op. cit. (41), 103.

51 Plantamour and Hirsch, op. cit. (21), 380.

52 Hirsch measured the precision of the Hipp chronoscope against a fall apparatus (la chute), which was frequently used to demonstrate the laws of physics. This consisted of dropping a ball from the same height a number of times and having the ball start the chronoscope at the instant it started falling and stop it at the end. The differences in the times shown by the chronoscope demonstrated to Hirsch that its average error did not surpass two thousandths of a second. The second test of the chronoscope was more difficult. It consisted of calibrating the instrument against a pendulum to make sure a measure of the chronoscope was identical to a measure of the pendulum. At first Hirsch did not have an automatic 'pendulum interrupter', so he calibrated Hipp's instrument by hand. He would simply open the chronoscope's circuit when the pendulum marked the start of a second, and would close it after the pendulum marked ten. Then he would equate the average measure shown by the chronoscope to ten pendulum seconds. In doing this manually, Hirsch acknowledged that 'undoubtedly, I introduce the physiological incertitude of this task into the determination of the chronoscope's speed', but assumed that by calibrating the chronoscope a large number of times (nearly fifty) the error would be minimized to attain 'a more than satisfactory exactitude'. Hirsch, op. cit. (41), 107. 
seem to me to have a special importance because they permit us to separate (up to a certain point) the first element of the temps physiologique. ${ }^{53}$ When experimenting on his colleague and friend Dr G. Guillaume, he noted that if a stimulus was applied to the right hand and the subject was asked to react, the temps physiologique was almost half as when the stimulus was applied to his right foot. Hirsch acknowledged part of the reason for the difference might be due to a 'different sensibility' of the hand and foot, but since the distance between the hand and the brain was almost half the distance between the foot and the brain, he concluded that the near doubling of the temps physiologique should mostly be due to the speed of transmission in sensory nerves. The technique of using different nerve lengths for separating the elements of the temps physiologique was described in Ule's letter, but Hirsch's results differed noticeably from those given in the summary of Helmholtz's work. While Hirsch found thirty-four meters per second for the speed of nervous transmission, Helmholtz had obtained 54.9 meters per second. Hirsch's results on humans, however, were compatible with Helmholtz's on frogs, 32.3 meters per second. Alarmed by the discrepancies, Hirsch once again retreated from enemy territory, drew the line between astronomical and physiological research, and called on the physiologists for help : 'it would be desirable for physiologists to use [my method] and develop it more than I can'. But they should use live humans, not dead frogs: 'It would be of great importance to repeat Helmholz's [sic] experiments, especially through a more direct method where one could experiment on the living nerves of man, instead of on frog nerves. ${ }^{54}$ While Schaffer found astronomers competently dealing from within their own discipline with the problem of personal differences in observation, in Hirsch's case the contrary is true, for he repeatedly performed experiments in physiology and asked physiologists for help.

From now on, Hirsch wrote, his experiments would only continue where they concerned astronomy, and he again contacted the 'Swiss Edison' (Hipp) to build for him an apparatus for measuring the temps physiologique involved in star transit observations. ${ }^{55}$ With this new apparatus, he could test an observer's reaction to artificial stars, instead of their reaction to tactual stimuli, which should concern primarily the physiologists.

In April 1863 Hirsch announced to the Sociéte his experiments on the determination of personal corrections in observations using the new, artificial star apparatus built by Hipp. ${ }^{56}$ This time Hirsch's experiments on the temps physiologique present in visual observations resembled more closely the actual observation of stellar transits, and he underscored the practical application of his research. With Hipp's apparatus, he timed an observer's reaction to the passage of an artificial star across the wires of a meridian telescope 'in the same way one observes the passage of a real star'. ${ }^{57}$ In both of his articles on the personal equation Hirsch underscored how it varied with time according to an 'observer's disposition at the time' and to the speed of a star's passage..$^{58}$ These variations due to the

53 Hirsch, op. cit. (41), 112.

54 Hirsch, op. cit. (41), 103.

55 De Mestral, op. cit. (39), 12.

56 Louis Favre, 'Séance du 24 avril 1863', BSN (1861 à 1864) (1864), 6, 305-8, 305.

57 Adolph Hirsch, 'Sur les corrections et équations personelles dans les observations chronographiques de passage', BSN (1861 à 1864) (1864), 6, 365-72, 367.

58 Hirsch, op. cit. (57), 369. 
bodily state of an observer corroborated Hirsch's central metaphor, the human body as a 'machine de precision'. ${ }^{59}$ 'Our body', he explained, 'is ... exactly like a precision machine' and, 'like a meridian instrument or a pendulum, its correction is variable'. ${ }^{60}$

Astronomers were closely watching Hirsch's results for they hinged on a question of capital importance: the reliability of the new electro-chronograph for time and longitude determinations. In fact Hirsch's research on the personal equation was part of his work on the difference in longitude between his observatory and Émile Plantamour's at Geneva. Hirsch was trying to kill two birds with one stone. At the same time, he sought to solve the problem of the personal equation and determine the difference in longitude between Neuchâtel and Geneva. Both of these endeavours were completely, and intricately, related. ${ }^{61}$

Hirsch and Plantamour's work on the difference in longitude between Neuchâtel and Geneva, of which Hirsch's work on the personal equation was an integral part, was an important test of the new electro-chronograph. ${ }^{62}$ One of the electro-chronograph's advantages over the eye-and-ear method was that, in a fixed interval of time, many more observations could be performed. This advantage, however, was countered by a considerably greater time needed in reading off the observations. ${ }^{63}$ Yet the average error in observations for Plantamour and Hirsch $(0.097$ seconds) rivalled those of 'the best

59 Hirsch, mistakenly, thought his conclusion on variability was novel, and most astronomers would cite it as the first convincing proof of the dangerous diurnal variation of the personal equation. His result was preceded in published form by the French astronomer Emmanuel Liais, 'De l'emploi des observations azimutales pour la détermination des ascensions droites et des déclinaisons des étoiles', Mémoires de la Société impériale des sciences naturelles de Cherbourg (1857), 5, 146-288. The journal where Liais published was not as widely read as, for example, the Comptes rendus de l'Académie des sciences. In the Comptes rendus Liais published an extract of his paper which did not include any mention of variability, idem, 'Sur un procédé pour substituer des opérations de pointé aux estimations de passages dans les observations astronomiques azimutales', Comptes rendus hebdomadaires (18 January 1858), 48, 131-3. In another paper on the personal equation also published in the Comptes rendus he again makes no mention of variability, 'Sur la valeur relative des divers modes de pointé avec le théodolite, et sur les équations personelles', Comptes rendus hebdomadaires (10 October 1859), 49, 494-9. This may help explain why Liais was not known to astronomers as the discoverer of variability in the personal equation. The variability of the personal equation was also remarked by Charles Babbage, who in his own personal notes revealed, 'There was however not merely a personal equation but a periodic personal equation. For I found on trial that my own accuracy ... varied with the state of bodily fatigue.' Charles Babbage, Papers on Astronomy, 1862, British Library Manuscript Collection. Italics original. These observations were alluded to much earlier, but without attributing them to the 'personal equation' in Charles Babbage, Reflections on the Decline of Science in England, and Some of its Causes, 1830; reprinted New York, 1970, 173-4. According to Otto Ule, Helmholtz also remarked on the variability of the personal equation due to an observer's degree of attention and 'suivant les dispositions du moment'. Ule, op. cit. (42), 202. Finally, Wilhelm Wundt described the variability of the personal equation in Wilhelm Wundt, Vorlesungen über die Menschen- und Thierseele, 2 vols., Leipzig, 1863.

60 Hirsch, op. cit. (57), 370

61 From the immediate goal of determining the difference in longitude between Neuchâtel and Geneva, Hirsch and Plantamour wanted to take the more ambitious step of telegraphically linking the Swiss observatories to Paris or London and, in doing so, to contribute to the vast geodesic enterprise of determining the shape of the Earth. Plantamour and Hirsch, op. cit. (21).

62 'Astronomers will find in this work the facts on the merits and faults of chronographs, used either inside observatories or at a distance.' Plantamour and Hirsch, op. cit. (21), 290.

63 'In fact, this advantage is countered by the time required to transcribe the chronographic observations.' Plantamour and Hirsch, op. cit. (21), 343. 
observers'. Furthermore, without performing any experiments on this issue, Plantamour and Hirsch assumed that the variability present in chronographic observation also appeared in the old eye-and-ear method - an assumption which would soon be proven wrong in Paris. ${ }^{64}$ For these reasons, the final verdict on the 'merits and faults of chronographs' was that observations were almost equally time-consuming and equal in exactitude, but use of the expensive electro-chronographs did not require skill. For the first time, precision could be achieved without having to be one of 'les observateurs les plus distingués' ${ }^{65}$

The first attempt of Plantamour and Hirsch to eliminate their personal equations (May 1861) was motivated by their work on the difference in longitude between Geneva and Neuchâtel. The traditional manner of eliminating the equations was for astronomers to switch stations so their personal corrections would cancel out. This, for example, was done in the longitude determination between Paris and Greenwich, where Edwin Dunkin and Hervé Faye changed places. Yet this method assumed the personal equation remained constant through time, and constant when observing with a different instrument. ${ }^{66}$ This was an assumption Plantamour and Hirsch could not make. In October of that same year they measured their personal equations by having one of them observe a star's passage across the first ten wires of the micrometer and the other across the last ten, and then by alternating the order. ${ }^{67}$ By determining the personal equation in this manner, however, Plantamour and Hirsch witnessed strange changes in their equations. ${ }^{68}$

Hirsch's work on astronomy and on the temps physiologique overlapped both temporally and textually. His ' On the corrections and personal equations of chronographic stellar transit observations', referred to 'Telegraphic longitude determination between the Geneva and Neuchâtel observatories’, and vice versa. In his later work in astronomy,

64 'The personal correction in stellar transit observations done with the American method (and by necessity for observations done with the eye-and-ear method), is not a constant quantity for individuals.' Plantamour and Hirsch, op. cit. (21), 393. Italics original.

65 Plantamour and Hirsch, op. cit. (21), 342.

66 'We must first assume that both observers using an uncustomary, foreign instrument observe in the same way as if they were using their own instrument.' Plantamour and Hirsch, op. cit. (21), 369.

67 According to Plantamour and Hirsch,

The method by which two astronomers alternately observe the passage of the same star through different wires of the meridian instrument is certainly better than the other method, where they alternately observe different stars, because it is independent of the pendulum's variation and of instrumental corrections.

Plantamour and Hirsch, op. cit. (21), 372.

68 The following month Hirsch presented to the Société his first attempts at 'measuring the elapsed time between the instant a phenomenon takes place and the time when an experimental subject acknowledges he has sensed that phenomenon', which were interrupted by the failure of his Hipp chronoscope. In April 1862 they continued measuring their personal equations for the immediate goal of finding the difference in longitude between Neuchâtel and Geneva, and still witnessed the worrisome variation in both of their personal equations. A month later, once the Hipp chronoscope was repaired, Hirsch undertook his influential 'chronoscopic experiments on the speed of the different senses and of nervous transmission', which corroborated his earlier observation of variability in an observer's personal equation. In November 1862, to continue their work for determining longitudes, they tried to measure their absolute personal equations with Hirsch's artificial stars. The results were announced to the Société on 24 April 1863. 
Hirsch and his colleagues continued to make contributions for eliminating the personal equation ('an important element, which, one must say, is usually the weak point of telegraphic longitude determinations') which could be considered physiological. For example, in an important study they noticed the personal correction for an observer varied with the adjustment of the ocular, and determined this was due to different (myopic, normal, presbyopic) eyes. ${ }^{69}$ Hirsch also tested whether changes in the direction of a star's transit, changes in its speed or the optical magnitude of a telescope affected an observer's personal correction. The effects of telescopic magnitude and the sense of stellar transit on the personal equation were particularly important for fieldwork, where observations were performed with a theodolite, and stars passed from left to right with a small telescopic magnitude. To test the personal equation on this instrument, Hipp modified Hirsch's artificial stars so speed and direction could be adjusted. ${ }^{70}$ Furthermore, Hirsch and his colleagues noticed diurnal changes of the personal equation were usually more marked than annual changes, and this licensed astronomers to use an averaged result for their equations, instead of having repeatedly to test observers. ${ }^{71}$

To find the difference in longitude between Simplon, Milan and Neuchâtel, Hirsch and Plantamour studied two different methods of observing with the electro-chronograph, which experimental psychologists would later classify in terms of reaction or muscular time. $^{72}$ The first method consisted of anticipating the time when a star would cross the wires of a transit instrument, while in the second method the observer waited until the star was bisected, and then pressed the key. Although the first method involved a smaller temps physiologique, according to Hirsch and Plantamour an observer should 'wait to see the bisection before giving the signal ${ }^{73}$ In their collaboration with Celoria, and their work with Hirsch's aide-astronome Alexander Schmidt, they noticed how observers could switch

69 Emile Plantamour, Rudolf Wolf and Adolph Hirsch, Détermination télegraphique de la différence de longitude entre la station astronomique de Righi-Kulm et les observatoires de Zurich et de Neuchâtel, Genève and Bâle, 1871, 1-220. Hirsch later learned Carlini had observed this phenomenon in 1819, who mentioned it in the Milan Ephemerides. For the preliminary work behind these longitude determinations see Louis Coulon, 'Séance du 6 juin 1867', BSN (1864 à 1867) (1867), 7, 550-8, 550-5.

70 The results were baffling. For Plantamour, neither telescopic magnitude nor direction affected his absolute personal equation; for Rudolf Wolf, changes in telescopic magnitude affected his personal equation noticeably, and Hirsch's equation suffered from both changes in telescopic magnitude and sense of stellar transit. Hirsch's findings were of international importance. Wilhelm Förster and Weiss found analogous changes in their personal equations for the determination of longitude between Berlin and Vienna; Bruhns and Weiss for Leipzig and Dablitz (in Bohemia); and Karl von Littrow presented to the Vienna Academy his research on this topic. Correspondence from Hirsch to von Littrow can be found at the Wiener Stadt- und Landesbibilothek, Vienna.

71 The conclusions from the longitude determination between Rigi-Kulm (Switzerland), Geneva, Zurich and Neuchâtel were used in Emile Plantamour and Adolph Hirsch, Détermination télegraphique de la différence de longitude entre des stations suisses, Genève and Bâle, 1872, and in Émile Plantamour and Adolph Hirsch, Détermination télegraphique de la différence de longitude entre la station astronomique du Simplon et les observatoires de Milan et de Neuchâtel, Genève, Bâle and Lyon, 1875. They used averaged results for the personal equation in Emile Plantamour and Adolph Hirsch, Détermination télegraphique de la différence de longitude entre l'Observatoire de Zurich et les stations astronomiques du Pfänder et du Gäbris, Genève, Bâle and Lyon, 1877.

72 'One knows that in fact there are two distinct ways of seizing the passage of stars in chronographic observations'. Plantamour and Hirsch, Détermination télegraphique de la différence de longitude entre la station astronomique du Simplon et les observatoires de Milan et de Neuchâtel, op. cit. (71), 110.

73 Plantamour and Hirsch, op. cit. (71), 111. 
back and forth between these two observing methods and make their personal equations unstable and unpredictable. Furthermore, they noticed Celoria's personal equation changed with the position of the ocular (west or east) and according to the angle of a star's transit across the view of the instrument. Hirsch again needed physiologists to solve this riddle: 'A similar influence on the manner of observing due to the positions of the instruments has been noticed by other astronomers, without there being a satisfactory physiological explanation ${ }^{74}$

\section{Edwin Dunkin at the Greenwich Observatory and Charles Wolf at the Imperial Observatory of Paris}

Hirsch's results did not go uncontested in astronomy. Although his conclusions on the electro-chronograph were not the same as those obtained at the venerable Greenwich Observatory, Hirsch boasted they were at least compatible: 'The results obtained by Dunkin are, for the most part, perfectly in accord with ours. ${ }^{75}$ The difference lay in Hirsch's 'discovery' of the short-term variability of the personal equation which, naturally, escaped Dunkin's year-long tests:

The variability of the physiological correction which we noticed is compatible with the yearly constancy of the personal equation noticed by Dunkin for observers at Greenwich. We have reasons to believe that one will notice in the observer's relative equations short-term variations, analogous to those revealed by the observation of artificial stars. ${ }^{76}$

Hirsch's hopes for confirmation of short-term variations backfired in Paris, where the astronomer Charles Wolf obtained contrary results. ${ }^{77}$

The variability of the personal equation, according to Wolf, was not entirely 'physiological', as Hirsch claimed. It was rather 'psychological' and could be eliminated through discipline and education. Once the 'psychological' element was eliminated, a constant 'physiological' time remained which could be easily measured and subtracted from observations. For Wolf, furthermore, the cause of this 'physiological' delay was completely different than for Hirsch. Hirsch knew of Wolf's work only through a short note which appeared in the Comptes rendus that did not contain a full report of his research. ${ }^{78}$ Yet this taste was enough for him to respond vehemently. Wolf only defended himself by cynically writing back, 'it is impossible for me to call a controversy which began in such a way a "discussion", for at first I even had to tell my antagonist the topic of

74 Plantamour and Hirsch, op. cit. (71), 121-2. One hypothesis, however was put forth: 'Il est donc probable à priori que l'influence de la direction sur les temps physiologique doit être une fonction de la hauteur de l'étoile'.

75 Plantamour and Hirsch, op. cit. (21), 434 n1.

76 Plantamour and Hirsch, op. cit. (21), 435 n1.

77 For Charles Wolf see Jimena Canales 'The single eye: re-evaluating ancien régime science', History of Science (2001), 39, 71-94.

78 Charles Wolf, 'Recherches sur l'équation personnelle dans les observations de passages, sa détermination absolue, ses lois et son origine', Comptes rendus hebdomadaires (19 June 1865), 60, 1268-72. The complete work appeared in idem, 'Recherches sur l'équation personnelle dans les observations de passages, sa détermination absolue, ses lois et son origine', Annales de l'Observatoire impérial de Paris, mémoires (1866), 8, 153-208. 
debate', and by putting the complete report in the mail. ${ }^{79}$ It is instructive, however, to follow Hirsch's defence in more detail, and to note the subsequent influence of Wolf.

In February and March 1866 Hirsch announced to the Société his criticisms of Wolf's work. These also appeared in a letter written to the renowned popularizer of science Rodolphe Radau, who had just published a history of personal errors that leaned sharply in Wolf's favour, and in 'New investigations on the personal equation', by an unknown author who defended Hirsch's results. ${ }^{80}$ In the letter to Radau, Hirsch questioned Wolf's interpretations of the results more than the results themselves. Hirsch's argument was not that Wolf's instrument gave erroneous results, after all his instrument was 'almost identical to the one I built and use'. ${ }^{81}$ The point of contention was the significance which should be given to the variability of the personal equation. Whereas Hirsch sought to measure and correct it as one would an instrumental error, Wolf wanted to educate astronomers to the point where it remained constant and could no longer be reduced, and then correct for the rest. According to Hirsch one did not have to eliminate this variability, which he attributed to a 'sluggishness of the mind', through discipline and education. The solution was to 'resign oneself to admit this sluggishness of the mind ... as an unfortunate characteristic of the astronomers' nervous system' ${ }^{82}$ One should do for the errors of the astronomers what one would do 'for the instruments - not to try to eliminate their errors, which is simply impossible, but to diminish them as much as possible'. ${ }^{83}$

For Hirsch, education and discipline were not a solution since the personal equation varied with the state of bodily fatigue of an observer. What Hirsch needed was well-rested, not skilled or disciplined, observers. ${ }^{84}$ Rest, felicitously, was an important factor for Hirsch, since he, unlike Le Verrier and George Airy, did not have observers and had to do most of the observations himself. ${ }^{85}$ 'This physiological variation', Hirsch repeatedly wrote, 'depends essentially on the disposition of observers at the time', ${ }^{86}$ and the constant,

79 Charles Wolf, 'Sur les erreurs personelles: Lettre de M. Wolf en réponse à la lettre de M. Hirsch', Le Moniteur scientifique: Journal des sciences pures et appliquées (25 April 1866), 8, 425.

80 Louis Coulon, 'Séance du 22 février 1866', BSN (1864 à 1867) (1867), 7, 264-9, 264-5; Louis Coulon, 'Séance du 22 mars 1866', in ibid., 275-6; Adolph Hirsch, 'Sur les erreurs personelles: lettre de M. A. Hirsch, directeur de l'Observatoire cantonal de Neuchâtel, à M. R. Radau', Le Moniteur scientifique: Journal des sciences pures et appliquées (1866), 8, 315-17; [Adolph Hirsch ?], 'Nouvelles recherches sur l'équation personelle', BSN (1864 à 1867) (1867), 7, 277-84. Although the 'Nouvelles recherches sur l'équation personelle' stated no author, only Hirsch's work is taken into consideration and defended. This led me to suppose that either Hirsch wrote it in the third person, or he collaborated closely with the author. Since the anonymous author stated that it was a faithful account of Hirsch's own views, I considered them as such.

81 Hirsch, op. cit. (80), 315-16.

82 Hirsch, op. cit. (80), 316

83 Hirsch, op. cit. (80), 316

84 The researchers noted,

In our discussion of chronographic observations we have seen that the personal equation can vary as much during the course of a day as from one day to the next. It is probable that the same thing happens in astronomical observations, and if observers rest for more or less long intervals during the night, their physiological disposition will have changed.

Plantamour and Hirsch, op. cit. (21), 391.

85 As noted before, Hirsch later had Schmidt, an aide-astronome, help him in observations, but he still did many of the observations himself.

86 Plantamour and Hirsch, op. cit. (21), 393. 
fatiguing attention required from observers negatively affected their 'disposition momentanée' ${ }^{87}$ For Hirsch, a fatigued - albeit disciplined - observer could only produce faulty observations.

Hirsch and Wolf disagreed on the role of discipline in the observatory. Ule, in turn, was convinced of the benefits of education. If the personal equation measured the speed of thought, and if it could be reduced through education, then, Ule believed, persons could become more intelligent through practice and discipline:

What prevents us from developing the organ of our intelligence through sound and sustained exercise? Why not aspire to virtuosity in the art of thought, from the moment it is demonstrated that it does not depend only on individual capacities, but that it can be the product of education and exercise ${ }^{88}$

Hirsch, however, was less hopeful than Ule with respect to the effect of exercise and education on the temps physiologique. Initially for him the temps physiologique was neither lower for skilled observers, nor more regular. ${ }^{89}$ This belief, however, was to change as his work developed.

The second criticism forwarded by Hirsch was based on Wolf's treatment of Bessel. His point was clear: 'The experiments of Wolf are not sufficient for refuting the principle of Bessel's explanation. ${ }^{90}$ Hirsch, after all, generally agreed with the explanation attributed to Bessel. It is important to note, however, that Hirsch's knowledge of Bessel's work on the personal equation might well be second-hand, most probably taken from Ule's letter and from an article by Faye, which appeared in the Comptes rendus, where Faye rephrased Bessel's interpretation. Bessel's authority spoke. Hirsch wrote that it was insolent and wrong for Wolf to 'doubt the "degree of education" of Struve and Bessel', two 'great astronomers', who both had large personal equations. ${ }^{91}$ Pace Wolf, who preached a return to the old eye-and-ear method, Hirsch did not stop defending the new electro-chronograph. 'There are reasons', he concluded, 'for introducing the chronographic method to almost all observatories'. ${ }^{92}$

After Wolf's initial criticisms, Hirsch joined many astronomers who believed the best solution to the personal equation problem was to eliminate the observer. ${ }^{93}$ The elimination of the observer, for example, was Faye's call after learning of the variability in the personal equation from Hirsch's work. ${ }^{94}$ Hirsch agreed the observer should be eliminated either with photography or by building an 'impersonal' micrometer, which would automatically

\footnotetext{
87 'This constant attention is excessively fatiguing, and explains the vexation produced by prolonged astronomical observation.' Adolph Hirsch, 'Sur quelques recherches récentes concernant l'équation personnelle et le temps physiologique’, BSN (1874 à 1876) (1876), 10, Appendix, 1-14, 6.

88 Ule, op. cit. (42), 202.

89 'Because even for highly skilled observers this time varies according to the observer's disposition at the time'. Hirsch, op. cit. (41), 103. Italics mine.

90 Hirsch, op. cit. (80), 316.

91 [Hirsch ?], op. cit. (80), 280.

92 Hirsch, op. cit. (80), 316.

93 On nineteenth-century 'mechanical objectivity' see Lorraine Daston and Peter Galison, 'The image of objectivity', Representations (1992), 40, 81-128.

94 Hervé Faye, 'Sur les erreurs d'origine physiologique', Comptes rendus hebdomadaires (12 September 1864), 59, 473-80.
} 
follow and record a star's transit across the sky. In his report for the years 1864 to 1865 Hirsch wrote, 'The variability of the temps phsyiologique which we have brought to light has provoked in many places suggestions for eliminating the observer, with photography or other recording mechanisms. ${ }^{95}$ Yet Wolf, once again, disagreed with Hirsch. For him, astronomy would always need observers. ${ }^{96}$ The disagreements did not stop there. Hirsch's efforts later in his life for a unified time represented for Wolf 'the tyranny of railway companies', which 'without thinking of the habits or legitimate needs of the public' imperiously imposed their needs. ${ }^{97}$ Wolf was certainly not alone in his anger towards the railway companies. Even Switzerland in the winter of 1867 saw a reaction, which culminated in their nationalization in 1898, against the privately owned railway companies headed by the 'federal magnate' Alfred Escher, bitterly known as the 'banklord' and the 'railway king'. ${ }^{98}$

A final point of disagreement between Hirsch and Wolf was about the strength of stellar effects on Earth and on an observer's eyes. While Wolf blamed most of the personal equation on the different times a star's afterimage remained in the observer's eyes, Hirsch believed this effect had been largely exaggerated, and could not exceed the value of 0.066 seconds. Hirsch kept abreast of recent developments - now seen as the birth pangs of astrophysics - which consisted of analysing light emitted from the stars, but he differed with Wolf on the strength of these stellar effects. ${ }^{99}$ For Hirsch the afterimage of stellar light on the retina could not account in toto for the temps physiologique. According to Hirsch, Wolf was wrong in attributing everything to the effect of stellar light on the eyes, and nothing to its effect on the brain: 'Wolf ignores the temps physiologique necessary for transmitting the image formed in the retina to the brain, and also the time taken by the central organ'. ${ }^{100}$ The seat of personal differences was different for Hirsch than for Wolf. While for Wolf they were due to different eyes and different degrees of education, for Hirsch they were mostly due to different brains. ${ }^{101}$ The 'New investigations on the personal equation' defending Hirsch's views claimed it was 'especially [the time taken by the brain] which varies from one individual to the next, and in the same individual, from one moment to another'. ${ }^{102}$ In the importance given to the brain, Hirsch followed Ule, who attributed the limitations in hearing or seeing rapid phenomena to the brain. Ule's answer to why a person could not see rapidly scintillating light was: "Why? Only because the phenomenon is faster than thought. It is the brain which is slow. ${ }^{, 103}$ Helmholtz (according

95 Hirsch, op. cit. (16), Appendix, 10. The same point was stated again in [Hirsch ?], op. cit. (80), 282-3. 96 Charles Wolf, 'Sur la comparaison des résultats de l'observation astronomique directe aves ceux de l'inscription photographique', Comptes rendus hebdomadaires (1 May 1886), 102, 476-7.

97 Charles Wolf, 'Le temps local et l'heure universelle', Revue pédagogique (October 1891), 19, 354-63, 356. 98 Georg Thürer, Free and Swiss: The Story of Switzerland (tr. R. P. Heller and E. Long), London, 1970, 121, $131-2$.

99 Hirsch, for example, commented on the work of Robert Wilhelm Bunsen and Gustav Robert Kirchhoff of Heidelberg on spectra. In Louis Coulon, 'Séance du 1 Novembre 1861', BSN (1861 à 1864) (1864), 6, 1-6, 6. 100 [Hirsch ?], op. cit. (80), 282.

$101 \mathrm{He}$ admitted variations of the temps physiologique should be due to both, the eyes and the brain, but the latter was overwhelmingly responsible.

102 [Hirsch ?], op. cit. (80), 282.

103 Ule, op. cit. (42), 199. 
to Ule) also believed personal differences in reaction time were mostly due to different brains.

\section{Sigmund Exner in Vienna}

After Hirsch's vehement response to Wolf and after more work on the personal equation, his views changed. First, Hirsch became aware of Schelske's work, and then Donders sent him a copy of his 'On the speed of mental processes'. ${ }^{104}$ Hirsch contacted du BoisReymond to learn more about Donders's measuring instrument. Modestly, he wrote, 'First let me confess my ignorance (of which, as an occasional defector from astronomy to physiology, I should not be too ashamed) of Donders's apparatus that he named (horribile dictu!) Noëmatograph or Noëmatachometer. ${ }^{105}$ Second, and more importantly, Hirsch engaged the work of the Viennese physiologist Sigmund Exner, who 'deals precisely with the personal equation' ${ }^{106}$ This can particularly be seen in his response, communicated to the Société in February 1874, to Exner's work. Hirsch lamented Exner did not know his work or that of other astronomers except by the review of them given by Radau. As a consequence, Exner inadvertently repeated much of Hirsch's work. In a letter to du BoisReymond, Hirsch defended his priority since he accused Exner's 'reaction time' of being his old temps physiologique in disguise. ${ }^{107}$ Yet in his response to Exner some differences with his original work on longitude determinations - and some concessions to Wolf - were evident, in particular in acknowledging the importance of education. Eventually Hirsch accepted that discipline and practice could increase the constancy of an observer's temps physiologique. ${ }^{108}$

From Radau's summary, Exner became aware that 'in their investigations the astronomers have undertaken all sorts of physiological experiments' and he sought to restore order by coining the term 'reaction time' instead of dealing with the variously opaque 'personal time', 'personal error', or 'personal differences'. ${ }^{109}$ Yet Exner's work did not stop with the astronomers' concerns, but went on to study the relation between reaction time and 'personality'. Since 1857 Ule had dreamed that the personal equation might eventually measure a person's personality. In his letter to Desor he wrote,

104 Hirsch learned of Schelske's work through Emil du Bois-Reymond, who sent him a copy. In a letter to du Bois-Reymond Hirsch wrote, 'Schelske's work naturally interested me very much, not only because his results compared to mine fall completely within the error-limits, but especially because his method, in essence, is based on the same principles as mine.' Adolph Hirsch to Emil du Bois-Reymond, 23 July 1864, Briefe von Adolph Hirsch, Sammlung Darmstädter, Staatsbibliothek Berlin.

105 Adolph Hirsch to Emil du Bois-Reymond, 13 February 1869, Briefe von Adolph Hirsch, Sammlung Darmstädter, Staatsbibliothek Berlin.

106 Hirsch, op. cit. (87), Appendix, 1-14, 1.

107 Adolph Hirsch to Emil du Bois-Reymond, 15 October 1873, Briefe von Adolph Hirsch, Sammlung Darmstädter, Staatsbibliothek Berlin.

108 'For astronomers the effect of exercise results in a greater constancy and not in a diminution of the "temps physiologique'.' Hirsch, op. cit. (87), Appendix, 8.

109 Sigm. Exner, 'Experimentelle Untersuchung der einfachsten psychischen Processe. Erste Abhandlung: Die persönliche Gleichung', Archiv für die gesammte Physiologie des Menschen und der Thiere, herausgegeben von Dr. E. F. W. Pflüger (1873), 7, 601-60, 608-9. See also idem, 'Experimentelle Untershuchung der einfachsten psychischen Processe. Zweite Abhandlung: Ueber Reflexzeit und Rückenmarksleitung', in ibid., (1874), 8, 526-37. 
Consequently when we speak of live, impassioned or intense minds, or of slow, cold and apathetic minds we are not merely employing simple figures of speech. Rather, we are signalling real aptitudes which can be appreciated and measured, and like all other faculties they are also affected by education. ${ }^{110}$

Hirsch and Exner also tested the feasibility of Ule's dream. According to Hirsch age had no influence. A short reaction time depended on a 'particular state of mind', characterized by an observer's 'strong attention' which 'should not be confused with a volitional act'. ${ }^{111}$ While Helmholtz (according to Ule) and initially Hirsch believed the personal equation measured the time of human volition, Exner disagreed. For him, and later for Hirsch, reaction time measured a particular state of attention, more than a person's personality or will. An observer with a calm personality, Hirsch observed, could well have a short reaction time: 'individuals used to being in a state of attention have a short reaction time, even if they have a phlegmatic temperament'. ${ }^{112}$ Caffeine and even a subcutaneous injection of morphine did not affect reaction time, but two bottles of Hochheimer, Vienna's local wine, were a different story. In an experiment performed by Exner, a drunken subject thought he was getting better at timing stars, while the contrary was happening: his reaction time was increasing significantly. During the experiment, Exner's subject suffered from heart problems, and Hirsch only said, 'I swear I have never done a similar experiment with our local Neuchâtel wine.' ${ }^{113}$ But aside from experimenting with Rheinwein, Exner and Hirsch trod very similar territories, and when Exner finally received Hirsch's work, he apologized profusely and relinquished some priority. ${ }^{114}$

Hirsch and Exner disagreed on the speed of nervous transmission. Exner stood by Helmholtz's sixty-two meters per second, which the Berlin physiologist Woldemar Baxt had shown varied with temperature. Hirsch then wrote to du Bois-Reymond asking 'if today the value $62 \mathrm{~m}$ [eters per second] is generally accepted in physiology as the classic number for nerve speed', and received a convincing negative reply. ${ }^{115}$ With the number still up in the air, Hirsch acknowledged 'the advantage of Baxt's method, which consists in excluding the brain's intervention from the experiment' by directly stimulating motor nerves and noting the involuntary contraction produced in the finger muscles. ${ }^{116}$ The 'special' importance Hirsch attributed in his early work to isolating the action of the brain remained strong throughout his work, and can particularly be seen in his praise of Baxt's work and in his criticism of Wolf's elision of the brain. With respect to maintaining the

110 Ule, op. cit. (42), 202.

111 For the importance of 'attention' in the history of modernity see Jonathan Crary, 'Attention and modernity in the nineteenth century', in Picturing Science, Producing Art, (ed. Caroline A. Jones and Peter Galison), New York, 1998, 475-99, and idem, Suspensions of Perception: Attention, Spectacle, and Modern Culture, Cambridge, MA, 1999.

112 Hirsch, op. cit. (87), Appendix, 5.

113 Hirsch, op. cit. (87), Appendix, 9.

114 Sigmund Exner, 'Experimentelle Untershuchung der einfachsten psychischen Processe. III. Abhandlung: Der persönlichen Gleichung zweiter Theil’, Archiv für die gesammte Physiologie des Menschen und der Thiere, herausgegeben von Dr. E. F. W. Pflüger (1875), 11, 403-32. See also idem, 'Experimentelle Untershuchung der einfachsten psychischen Processe. IV Abhandlung: Die Empfindungszonen des Sehnervenapparate', in ibid., 581-602.

115 Hirsch, op. cit. (87), Appendix, 12.

116 Hirsch, op. cit. (87), Appendix, 14. 
disciplinary status quo between himself and the physiologists, with time he grew more and more impatient: 'while I wait for physiologists to solve these complicated questions, I will repeat my experiments on more individuals'. ${ }^{117}$

\section{Clockwork human}

Hirsch knew an explanation for an astronomer's foray into physiologist territory was necessary, and he commenced as follows: 'Among the astronomer's precision instruments lies the nervous apparatus of the observer. And it is important to determine its instrumental error, just like with any other instrument. ${ }^{118}$ In a sense, Hirsch was reviving the old Aristotelian-Galenic argument questioning the reliability of the senses, yet his solution to the problem was innovative. For Hirsch not only the senses were unreliable, so too were precision instruments, and they were both unreliable in the same way. According to Hirsch the methods used for correcting instrumental errors should be applied to the observer.

For Hirsch precision instruments were not as unproblematic as we generally think. ${ }^{119}$ Instruments - like observers - suffered from 'individuality'. Just as personal differences affected observations, two different chronographs produced different results. For this reason, Hirsch and Plantamour made sure the instruments on the Neuchâtel and Geneva stations were as similar as possible to reduce 'the individuality of the apparatus' ${ }^{120}$ In his work on the personal equation Schaffer has explained how in the nineteenth century observers were increasingly treated as being part of astronomical instruments. To this I want to add that in Hirsch and Plantamour's work, instruments were treated as part of the artisan, and subjected to the same faults. Adolphe Quételet's explanation of individuality, for example, was symmetrical in exactly this sense: just as two persons could never be identical, it was also impossible for two persons to create identical works. ${ }^{121}$ Quételet, who also worked on the personal equation, explained how if thousands of persons would copy the famous statue of the Gladiator, the sculptures would differ from each other, and the differences would follow his famous bell-shaped curve. The measurements of the persons who sculpted the Gladiators, in turn, would also follow the bell-curve, and vary in the same way as those of the sculptures they copied. In Hirsch, as in Quételet, both creator (instrument-maker) and creation (instrument) were subject to the same rules of individuality.

Hirsch and Plantamour experimented with different options for eliminating the individuality of their instruments. First, they tried to solve it in the same way they initially tried to solve the problem of the personal equation: by interchanging the instruments from the two stations in the same way Dunkin and Faye switched stations in the hope of

117 Hirsch, op. cit. (87), Appendix, 14.

118 Hirsch, op. cit. (41), 100.

119 For work which has questioned the traditionally unproblematic notion of instruments see H. O. Sibum, 'Reworking the mechanical value of heat', Studies in History and Philosophy of Science (1995), 26, 73-106 and Klaus Staubermann, 'Controlling vision: the photometry of Karl Friedrich Zöllner', (Ph.D. thesis, Cambridge University, 1998).

120 Plantamour and Hirsch, op. cit. (21), 396.

121 Adolphe Quételet, 'Lettre XX', in Lettres à S. A. R. le duc régnant de Saxe-Coburg et Gotha, sur la théorie des probabilités, appliquée aux sciences morales et politiques, Brussels, 1846, 133-8. 
cancelling out their personal equations. Nevertheless, this solution was not feasible since the instruments were too large to be moved and would inevitably suffer from transportation and reinstallation. ${ }^{122}$ Second, they tried to use instruments that were almost identical and, if possible, built by the same artisan: 'It is desirable that all of the instruments employed in both observatories be as similar as possible'. Finally, Hirsch and Plantamour undertook a detailed study of 'the individuality of the electromagnets', ${ }^{123}$ to make sure the main parts of the two electro-chronographs were as identical as possible. ${ }^{124}$ Good observers, like good precision instruments, were characterized not by the size of errors but by their constancy, yet even the exactitude of precision instruments - like that of observers - inevitably varied with time: 'The instrumental corrections themselves', they lamented, 'cannot be determined with an absolute exactitude and, besides, one cannot assume that they remain absolutely constant through the course of a night' ${ }^{125}$ Exner, Hirsch wrote, was wrong in saying good observers were characterized by a short reaction time; what mattered, rather, was the constancy of their observations: 'Just like the quality of our precision instruments does not depend on the size of their errors but on their constancy, so it is the constancy and not the size of his personal correction which characterizes a good observer. ${ }^{126}$ Hirsch applied clockwork industry truisms to observers.

\section{Conclusion}

In his work Hirsch was negotiating the defining characteristics of nineteenth-century objectivity. Only by measuring the personal equation could one 'come closer to the truth ${ }^{127}$ For Hirsch and his colleagues there was no single way of gaining objectivity, but rather many paths that had to be constantly negotiated and renegotiated. Consensus was hard to come by. Astronomers considered longitude and time determinations the crowning achievement of precision science, and as they debated the merits of different methods they touched on a broader question: how to be accurate. The debate on the electrochronograph, for example, encapsulated astronomers' views on mechanical objectivity. Did mechanical objectivity, they asked, eliminate the feared physiological element, or did the old eye-and-ear method give better results? Involved in the debate on mechanical objectivity were the astronomers' views on the role of education, skill and discipline. A question they asked was: is an observer skilled in the eye-and-ear method better than an unskilled observer using the electro-chronograph? They debated whether one should focus on education and discipline, or rather on eliminating fatigue. Maybe, some argued, the best way to achieve precision was to have a small observatory, or to mechanize observations to completely eliminate observers.

122 'The apparatus used in Geneva has the advantage of being simple and transportable, while the chronograph at Neuchâtel is a very heavy machine which is essentially fixed. This prevents us from exchanging the two instruments for eliminating their equations.' Plantamour and Hirsch, op. cit. (21), 310.

123 Plantamour and Hirsch, op. cit. (21), 294.

124 'The motor force, the regulator of the mechanism which makes the sheets of paper advance, the pens which mark the signals, the electro-magnets, and their batteries are almost identical.' Plantamour and Hirsch, op. cit. (21), 296.

125 Plantamour and Hirsch, op. cit. (21), 355.

126 Hirsch, op. cit. (87), Appendix, 3. Italics original.

127 Hirsch, op. cit. (41), 101. 
Hirsch broke Comte's disciplinary hierarchy by letting astronomy depend on physiology, and this disciplinary breach let loose debates on how to 'come closer to the truth'. At issue in the various paths to objectivity were national-and even personal-interests. Astronomers, for example, disagreed on the role the state should take in 'scientific matters', like standardization of weights, measures and longitudes or unification of time. While the fervently impious Hirsch dedicated himself to these tasks, for the deeply religious Wolf state intervention in favour of scientific concerns represented the tyrannical imposition of 'scientific truth' on 'moral truth'. ${ }^{128}$ Scientific authority, like the needs of state, also had a different hold on Wolf than on Hirsch. With Wolf, Bessel's untouchable observations and conclusions were mistrusted, destroying the standard explanation of personal differences in observation which had prevailed since the time Bessel allegedly coined the term 'personal equation'. In their search for precision, and especially in their contributions to physiology, astronomers gave a different shape to their conception of 'man'. They, for example, disagreed on the seat of personal differences. Did it lie in different levels of education, skill or ability? Different brains or different eyes? The importance given to the brain, furthermore, was connected to the strength attributed to astrophysical effects. Was what astronomers saw mostly due to the strength of astrophysical effects on eyes, or on their brains? Finally, they disagreed on how an observer was similar or different from an instrument, and on how they should deal with the idiosyncrasies of instruments arising from their individualité.

Different astronomers gave different answers to these questions, and through debate they clarified their different ideals of objectivity and their different conceptions of 'man'. A close look at Hirsch's work and at his reaction to work performed in other observatories reveals a complex discourse behind the astronomers' drive for accuracy. Part of this effort lies in Hirsch's call for help to the physiologists, and his own investigations in physiologist territory. For him objectivity could not be achieved in astronomy without physiology, and this led him to make, simultaneously, important contributions in both areas. Disciplinary transgressions, in this case between human physiology and astronomy, were essential for Hirsch. By studying an astronomer's call for experimenting on humans and not frogs, we can explore the forgotten common ground between the physical sciences and the sciences of man, and bring together the severed histories of objectivity and the body.

128 For Hirsch's position see R. Gautier, 'L'unification des longitudes et l'introduction d'une heure universelle', Archives des sciences physiques et naturelles (1884), 11, 593-617. For Wolf's see Wolf, op. cit. (97), 357. 